\title{
Atmospheric effects of volcanic eruptions as seen by famous artists and depicted in their paintings
}

\author{
C. S. Zerefos ${ }^{1,2}$, V. T. Gerogiannis ${ }^{3}$, D. Balis ${ }^{4}$, S. C. Zerefos ${ }^{5}$, and A. Kazantzidis ${ }^{4}$ \\ ${ }^{1}$ National Observatory of Athens, Athen, Greece \\ ${ }^{2}$ Academy of Athens, Athen, Greece \\ ${ }^{3}$ National Meteorological Service, Athen, Greece \\ ${ }^{4}$ Laboratory of Atmospheric Physics, Aristotle University of Thessaloniki, Thessaloniki, Greece \\ ${ }^{5}$ School of Architecture, National Technical University of Athens, Athen, Greece
}

Received: 26 February 2007 - Published in Atmos. Chem. Phys. Discuss.: 16 April 2007

Revised: 12 July 2007 - Accepted: 26 July 2007 - Published: 2 August 2007

\begin{abstract}
Paintings created by famous artists, representing sunsets throughout the period 1500-1900, provide proxy information on the aerosol optical depth following major volcanic eruptions. This is supported by a statistically significant correlation coefficient (0.8) between the measured redto-green ratios of a few hundred paintings and the dust veil index. A radiative transfer model was used to compile an independent time series of aerosol optical depth at $550 \mathrm{~nm}$ corresponding to Northern Hemisphere middle latitudes during the period 1500-1900. The estimated aerosol optical depths range from 0.05 for background aerosol conditions, to about 0.6 following the Tambora and Krakatau eruptions and cover a period practically outside of the instrumentation era.
\end{abstract}

\section{Introduction}

Man-made forcing of climate change is complicated by the fact that it is superimposed on natural climate variability. This natural variability on decadal to century time scales includes, among others, the variability in volcanic stratospheric aerosols and atmospheric transparency. Intense optical phenomena observed worldwide during sunsets following major volcanic eruptions, caused by volcanic aerosols injected in the stratosphere which remained there for a period of few years after the eruption, have been reported by several authors (Symons, 1888; Sandick, 1890; Sapper, 1917; Shaw, 1936; Hymphreys, 1940; Lamb, 1970; Deirmendijian, 1973). Prominent among them are the eruptions of Awu (Indonesia-1641), Katla (Iceland-1660), Tongkoko (Indonesia-1680), Laki (Iceland-1783), Tambora (Indonesia1815), Babuyan (Philippines-1831), Coseguina (Nicaragua1835), and Krakatau (Indonesia-1680, 1883). These optical phenomena have been attributed to the enhanced forward

Correspondence to: C. S. Zerefos

(zerefos@geol.uoa.gr) scattering caused by the volcanic aerosols in the stratosphere (Deirmendijian, 1973).

The effects of volcanic eruptions on climate along with volcanic indices of importance to climate have been recently discussed in the literature (Robock, 2000; Zielinski, 2000; Robertson et al., 2001). Volcanic aerosol indices include the Dust Veil Index (DVI), the Volcanic Explosivity Index (VEI) as well as ice core sulphate Index which can go back to 1500 (Lamb, 1970; Zielinski, 2000; Newhall and Self, 1982).

The earliest compilation is the DVI, introduced by Lamb (1970, 1977, 1983). It extends from 1500 to 1983 and is based primarily on historical accounts of optical phenomena while surface radiation measurements were used when available. In a few cases, reports of cooling associated with volcanic aerosols were incorporated into the index. Robock (1981) introduced a latitudinally dependent estimation of the DVI. Sato et al. (1993) produced a zonally averaged compilation of optical depth for volcanic eruptions from 1850 . The observational sources of this data set are similar to the DVI in addition to land-based pyrheliometric measurements of atmospheric extinction for the period after 1882. Stothers (1996) has improved upon the Sato et al. (1993) reconstruction for the period 1881-1960 by incorporating more pyrheliometric data from stations primarily in the Northern Hemisphere. Stothers (1996) also used historical accounts of starlight extinction, purple twilight glows, and other turbidity indicators to support and expand upon the pyrheliometric data.

Ice cores offer another valuable opportunity to reconstruct volcanic aerosols through the measurements of volcanic sulfate $\left(\mathrm{SO}_{4}^{2-}\right)$ deposited on glacial ice in the years immediately following an eruption. Portions of the technique were initially developed by Hammer et al. (1980) and Clausen and Hammer (1988). They used the record of bomb fallout in Greenland to obtain a mass of $\mathrm{H}_{2} \mathrm{SO}_{4}$ produced in the stratosphere from an individual eruption. They then accounted for the latitude of the eruption by employing an appropriate

Published by Copernicus Publications on behalf of the European Geosciences Union. 
multiplier within the calculations. Zielinski (1995) expanded on the technique by calculating the total $\mathrm{H}_{2} \mathrm{SO}_{4}$ aerosol loading and then ultimately, the optical depth $\left(\tau_{D}\right)$ using the relationship defined by Stothers (1984a). However, when the resulting ice core-derived $\tau$-values for the GISP2 (Greenland Ice Sheet Project Two) core were calibrated with other independent optical depth measurements it was found that equivalent optical depth measurements were obtained in some cases, but the ice core estimates were 2-5 times greater in others. This was especially true for mid-latitude northern hemisphere eruptions where there may have been some tropospheric transport of $\mathrm{H}_{2} \mathrm{SO}_{4}$ to polar ice sheets, and thus an enhanced signal. The high temporal resolution (annual to biennial), the length of the records, and the low temporal error (e.g. \pm 2 years for uppermost part of the GISP2 core) available in many ice core records allow for the reliable quantification of the atmospheric impact of past volcanism prior to the period of reliable historical observations. The GISP2 ice core has been used to create a 2100-year record of stratospheric loading and optical depth estimates. Robock and Free $(1995,1996)$ pioneered the use of sulfate data from multiple ice cores to construct a record of volcanic activity. Robertson et al. (2001) produced a high-resolution time and latitude-dependent estimate of stratospheric optical depth stretching back to 1500 by combining historical observations, ice core data from both Greenland and Antarctica, as well as recent satellite data. They also incorporated ice core data that were unavailable for the previous reconstructions and avoided ice cores that were less well dated or strongly complicated by non-volcanic aerosols.

The present work aims at providing a new look at the reconstruction of the aerosol optical depth before, during and after major volcanic eruptions by studying the coloration of the atmosphere in paintings which portrayed sunsets in the period 1500-1900, i.e. when atmospheric observations were scarce and mostly non-existent. This was done by measuring the red to green ratios of more than 500 paintings as well as using model calculations to simulate and calibrate the measurements from the coloration in paintings as described in the following text.

\section{Methodology}

\subsection{Criteria in selecting paintings}

Paintings representing sunsets throughout the period 1500 1900 form the source of the observational material in this study. Most of these paintings were available in digital form at the official web sites of 109 museums and galleries (see http://www.noa.gr/artaod for more details). In the 400-year period of study (1500-1900) eleven major volcanic eruptions have been observed characterized by DVI larger than 250 (Lamb, 1970). In that same period, but only for eight of these eruptions, we have found a number of 554 paintings from 181 painters, which have been divided into two groups: the group of "volcanic sunset paintings" and the group of "non-volcanic sunset paintings". The "volcanic sunset paintings" include those that were created within a period of three years that followed a major volcanic eruption. The rest of the paintings were considered to represent the background coloration of sunsets. Fifty four "volcanic sunset paintings" were found from 19 painters that fulfilled the above criteria and each of them was dated. Notable among the painters are Claude Lorrain, John Singleton Copley, Friedrich Caspar David, Joseph Mallord William Turner, Breton Jules, Edgar Degas, Alexander Cozens and Gustav Klimt. A complete list of all painters and paintings considered in this study can be found at http://www.noa.gr/artaod. A number of these paintings have not been included because of lack of information on the date of their creation.

\subsection{Chromatic ratio}

In order to characterize the redness of the sunset sky, the chromatic ratio R/G was calculated from the RGB values measured on the digitized paintings and when possible, also the solar zenith angle pertaining to each painting. For the calculation of the $\mathrm{R} / \mathrm{G}$ ratio we averaged the measured values over the field of view of the artist near the horizon. Red, so as green, yellow and blue, is a unique hue and by definition it cannot be described by the other unique hue alone or in combination (Wyszecki and Stiles, 1982). Each unique hue refers to the perceptual experience of that hue alone. Perceptual opponency of red/green forms the conceptual basis for quantifying the redness of monochromatic light. In a classic study, Jameson and Hurvich (Jameson and Hurvich, 1955) reasoned that the amount of redness in a monochromatic light can be measured by combining it with a second light that appears green when viewed alone (Shevell, 2003). It should be noted that color appearance is reasonably stable with increasing age of the painter (Schefrin and Werner, 1990). Therefore, it is expected that abnormalities seen in time series of $R / G$ values for each painter cannot be attributed to digression of the painters colour acuity due to age and could present colour perception of real natural abnormalities, such as those following eruptions, or abnormalities caused by psychological or cultural reasons. Thus R/G ratios can provide information on the perception of colours by the painter which are practically independent of aging and therefore they may be suitable to examine deviations of $\mathrm{R} / \mathrm{G}$ values from those that correspond to background atmospheric conditions at the time of the creation of the work of art.

\subsection{Model description}

In this study, the UVspec model (Mayer and Kylling, 2005; Kylling et al., 1998) from the LibRadTran package (http: //www.libradtran.org) was used to simulate the R/G ratios determined from the paintings. The model uses the 


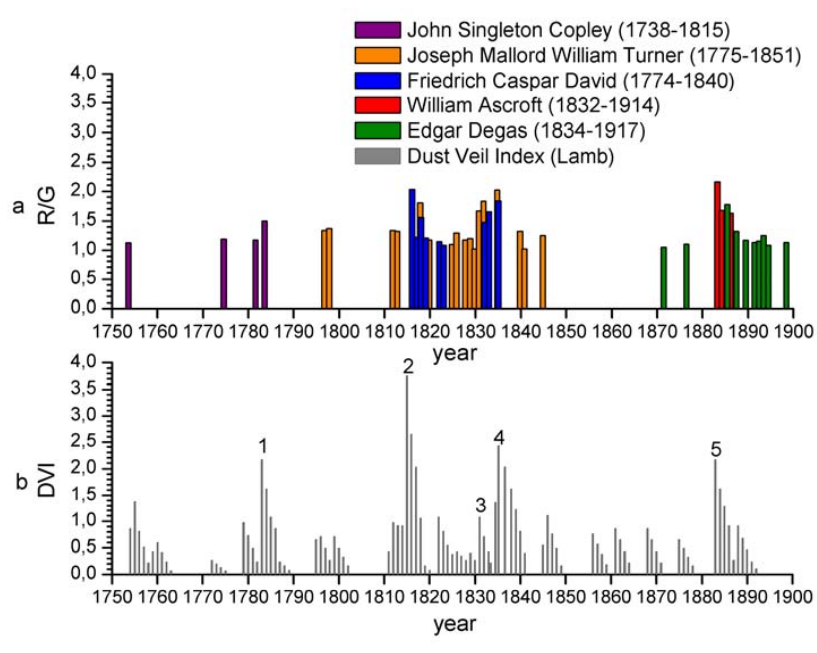

Fig. 1. (a) The variation of the chromatic ratio R/G that correspond to paintings of Copley, Turner, David, Ascroft and Degas. (b) The Dust Veil Index. The numbered peaks are 1. Laki, 2. Tambora, 3. Babuyan, 4. Coseguina and 5. Krakatau.

pseudo-spherical DISORT (Stamnes et al., 1988) to solve the radiative transfer equation using 16 streams. Irradiance and radiance spectra were calculated at $10 \mathrm{~nm}$ resolution and for the 15- to 85 degrees of solar zenith angle. The atmospheric composition and structure as used in the model was based on vertical profiles taken from the literature. The AFGL midlatitude winter profiles were used for ozone, temperature and air pressure (Anderson et al., 1986). Rayleigh scattering crosssections were calculated according to the analytic function proposed by Nicolet (1984). In this paper we calculated the direct and diffuse irradiance for the visible wavelength range (400-700 nm) for four stratospheric aerosol scenarios, keeping all other input parameters constant. The aerosol scenarios considered were a background stratospheric profile of the aerosol extinction and three aerosol profile that corresponds to moderate, high and extreme volcanic dust. The runs were repeated for AOD values at $550 \mathrm{~nm}$ from 0 to 2 with a step of 0.01 . From the above model runs estimates of the R/G ratios were determined by the model for various combinations of the aerosol model and the aerosol optical depth, and these estimates were compared to the ones that obtained from the paintings. The $\mathrm{R} / \mathrm{G}$ ratio was approximated using the ratio of the diffuse irradiance of two wavelengths $(550 \mathrm{~nm}$ and $700 \mathrm{~nm}$ ) rather than the radiance. The reason for using this approximation is discussed in more detail in Sect. 3.4. This comparison allowed us to associate to each painting an estimate of the aerosol optical depth during the time of creation.

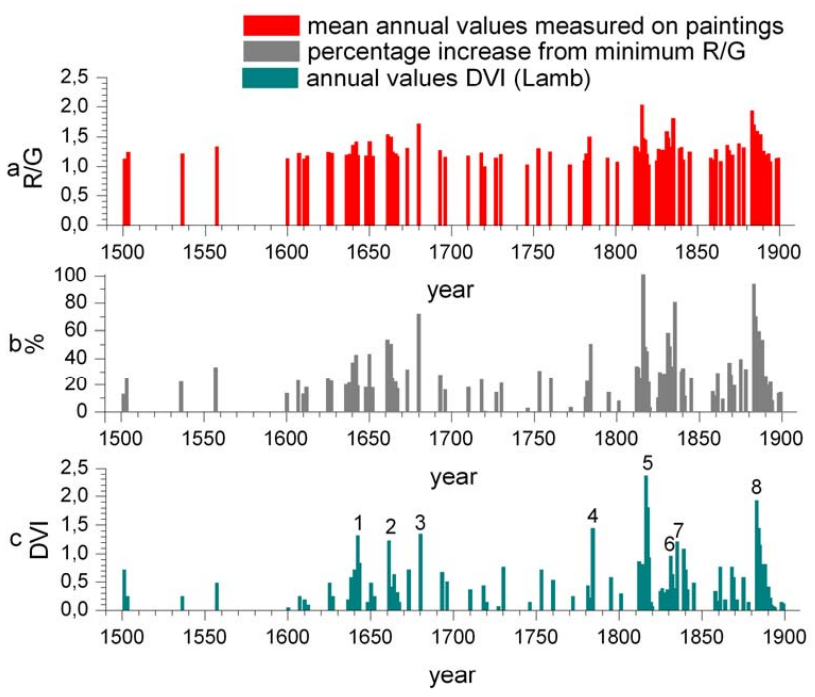

Fig. 2. (a) The mean annual value of R/G measured on 327 paintings. (b) The percentage increase from minimum $R / G$ value shown in (a). (c) The corresponding Dust Veil Index (DVI). The numbered picks correspond to different eruptions as follows: 1. 1642 (Awu, Indonesia-1641), 2. 1661 (Katla, Iceland-1660), 3. 1680 (Tongkoko \& Krakatau, Indonesia-1680), 4. 1784 (Laki, Iceland-1783), 5. 1816 (Tambora, Indonesia-1815), 6. 1831 (Babuyan, Philippines1831), 7. 1835 (Coseguina, Nicaragua-1835),. 8. 1883 (Krakatau, Indonesia-1883).

\section{Results and discussion}

\subsection{Chromatic ratios in art paintings at sunset versus DVI}

Our analysis began by examining the artist's perception of sunsets by measuring chromatic ratios during each artist's lifetime. Very few artists have painted sunsets before, during and following major volcanic eruptions. We found only 5 painters which in their lifetime have painted sunsets in all these three categories. The time series of the $\mathrm{R} / \mathrm{G}$ ratios for these five discreet painters is shown in Fig. 1 together with the corresponding series of DVI. We can see from Fig. 1 for example, that John Singleton Copley has "painted" an enhancement of 33\% relative to a minimum R/G value in 1784 . Joseph Mallord William Turner "painted" enhancements of $76.7 \%$ in $1818,79.2 \%$ in 1832 and $97,7 \%$ in 1835 , while Friedrich Caspar David observed enhancements of $89.5 \%$ in 1816, 51.3\% in 1833 and $41.2 \%$ in 1835 . Similarly Edgar Degas observed an enhancement of $68.4 \%$ in 1885 . As can be seen from Fig. 1 the R/G value measured on paintings corresponding to a volcanic event, are 1.3-1.4 times greater than the $R / G$ values before and after the event. Therefore, the observed departures of R/G chromatic ratios seen in Fig. 1, which coincide in time with major volcanic eruptions, can be tentatively attributed to the volcanic events and not to abnormalities in the color degradation due to age or other random factor affecting each painter's color perception. Figure 2 
Table 1. Estimated aerosol optical depth at $550 \mathrm{~nm}$ corresponding to middle latitudes for each major volcanic eruption from this papers in comparison with other studies.

\begin{tabular}{lllll}
\hline \multicolumn{2}{l}{$\begin{array}{l}\text { Volcano } \\
\text { Name }\end{array}$} & $\begin{array}{l}\text { Year of the } \\
\text { eruption }\end{array}$ & AOD this study & Nearest estimate from other studies \\
\hline 1 & Awu & 1641 & 0.35 & 0.33 (Zielinski, 2000) \\
2 & Katla & 1660 & $0.29-0.34$ & N/A \\
3 & $\begin{array}{l}\text { Tongkoko \& } \\
\text { Krakatau }\end{array}$ & 1680 & 0.47 & N/A \\
4 & Laki & 1783 & 0.30 & $0.21-0.28$ (Robertson et al.,2001) \\
& & & 0.19 (Robock and Free, 1996) \\
& & & 0.12 (Zielinski, 2000) \\
5 & Tambora & 1815 & $0.33-0.60$ & 0.5 (Robertson et al., 2001) \\
& & & 0.5 (Robock and Free, 1996) \\
& & & $0.2-0.9$ (Stothers, 1996) \\
6 & Babuyan & 1831 & $0.28-0.29$ & 0.24 (Zielinski, 2000) \\
7 & Coseguina & 1835 & 0.52 & $0.11-0.21$ (Robertson et al., 2000) \\
8 & Krakatau & 1883 & $0.37-0.57$ & 0.6 (Deirmendijian, 1973) \\
\hline
\end{tabular}

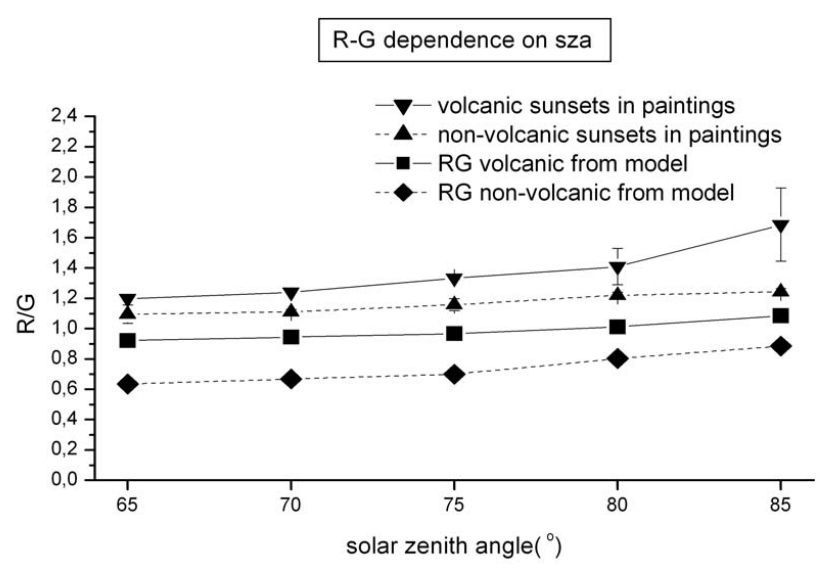

Fig. 3. The dependence of the chromatic ratio R/G on solar zenith angle as estimated from the paintings and the model. The volcanic sunset values include sunsets that were painted within a period of 3 years following a volcanic eruption. The non-volcanic sunsets include the remaining paintings at least 3 years apart from a volcanic eruption. The modeled $\mathrm{R} / \mathrm{G}$ diffuse irradiance $(\mathrm{R}=700 \mathrm{~nm}$, $\mathrm{G}=550 \mathrm{~nm}$ ) calculated for background aerosol and high volcanic aerosol.

shows mean annual values of $\mathrm{R} / \mathrm{G}$ sunset ratios measured from paintings along with the percentage increase from the absolute minimum $\mathrm{R} / \mathrm{G}$ value in the series (middle curve) together with the corresponding DVI values during 1500-1900. We note here that Fig. 2 includes 327 paintings, from a total of 554 examined, that fulfilled the criteria mentioned before and that their date could be determined or estimated. From that figure we see an enhancement of mean annual $\mathrm{R} / \mathrm{G}$ relative to the absolute minimum $\mathrm{R} / \mathrm{G}$ value. The numbered picks in that figure correspond to different eruptions as follows: 1. 1642 (Awu, Indonesia-1641), 2. 1661 (Katla, Iceland-1660), 3. 1680 (Tongkoko \& Krakatau, Indonesia1680), 4. 1784 (Laki, Iceland-1783), 5. 1816 (Tambora, Indonesia-1815), 6. 1831 (Babuyan, Philippines-1831), 7. 1835 (Coseguina, Nicaragua-1835),. 8. 1883 (Krakatau, Indonesia-1883). As seen from Fig. 2, there is a remarkable correspondence between peaks in $\mathrm{R} / \mathrm{G}$ values in years close to those with major volcanic eruptions. The linear correlation coefficient between mean annual R/G values and DVI was found to be $r=0.827$ based on 88 pairs, which is of high statistical significance.

3.2 Dependence of the chromatic ratio on the solar zenith angle

The dependence of $\mathrm{R} / \mathrm{G}$ ratios on solar zenith angle was studied by measuring the zenith angle with the following method: Wherever the exact date (time, day, year) and place of the painting is known, the solar zenith angle was computed. When that information was not available, the elevation of the sun was measured from the horizon and with the help of a fixed reference point on the painting, the solar zenith angle was calculated trigonometrically. In cases of uncertainty and when possible, the geometry of shadows provided additional help in approximating the solar zenith angle.

Figure 3 presents the variation of the measured R/G ratios versus the solar zenith angle averaged in $5^{\circ}$ bins, for the two groups of volcanic and non-volcanic sunset paintings. In addition Fig. 3 shows the R/G ratios calculated from the model for the same solar zenith angles. The model calculates the diffuse irradiance ratio $\mathrm{R} / \mathrm{G}$ computed for background aerosols and high volcanic aerosols. The wavelengths used are: $\mathrm{R}=700 \mathrm{~nm}$ and $\mathrm{G}=550 \mathrm{~nm}$. Both in paintings and the model, the $\mathrm{R} / \mathrm{G}$ ratio in the volcanic sunsets is higher than 


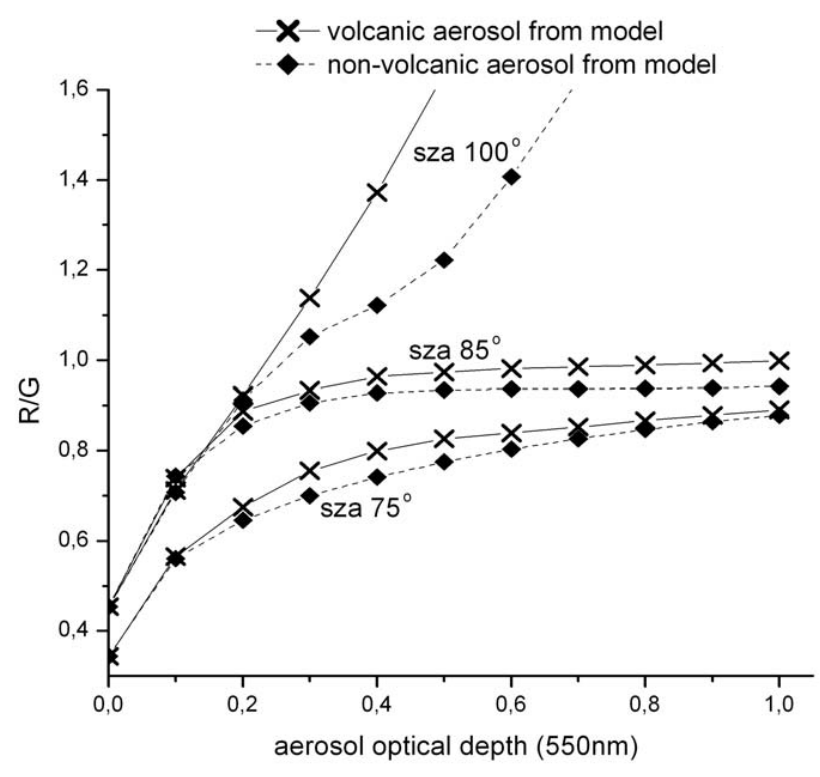

Fig. 4. Nomogramm of $\mathrm{R} / \mathrm{G}$ and aerosol optical depth as resulted from the model for three solar zenith angles calculated for nonvolcanic and volcanic aerosols used to calibrate the measurements on paintings.

the non-volcanic. This can be explained by Mie scattering, caused by the sulfate aerosol particles that are about the same size as the wavelength of visible light, which enhances the scattered radiation in the forward direction (Robock, 2000). For solar zenith angles greater than $80^{\circ}$ the chromatic ratio $\mathrm{R} / \mathrm{G}$ in the paintings is 1.4 times greater than the nonvolcanic. The model shows that the ratio $\mathrm{R} / \mathrm{G}$ due to extreme volcanic aerosols is 1.45 to 1.25 larger when compared to the ratio calculated for the background aerosols. As we see from Fig. 3, the model results when compared to the measured $\mathrm{R} / \mathrm{G}$ ratios on paintings show a systematic bias of about $30 \%$. The possible source for this bias is discussed in detail in section 3.4. This bias was also confirmed by examining $\mathrm{R} / \mathrm{G}$ ratios for "Krakatau" paintings, and from other measurements and our estimates of the optical depth of the volcanic debris. This was done by measuring $\mathrm{R} / \mathrm{G}$ ratios in $\mathrm{W}$. Ascroft color drawings of sunsets which followed Krakatau in London (Symons, 1888). These color drawings have been constructed at known solar zenith angles of $92.6^{\circ}$ and $99.5^{\circ}$, as calculated from time, date and month and London's geographical coordinates.

\subsection{Estimates of optical depth}

To estimate the optical depth which could be attributed to each volcanic eruption, a nomogram of $R / G$ values and aerosol optical depth was constructed for volcanic and nonvolcanic aerosols using the UVspec model for three solar zenith angles as seen in Fig. 4. Before that the observed arbitrary $\mathrm{R} / \mathrm{G}$ ratios have been adjusted for the systematic

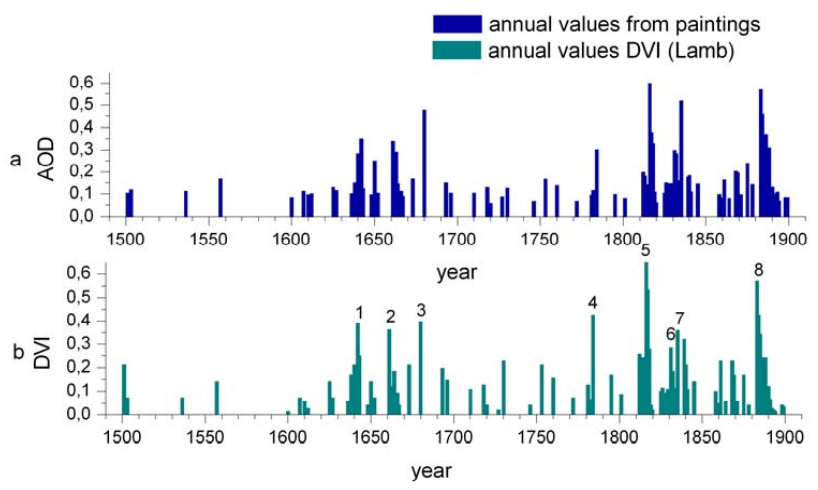

Fig. 5. (a) The aerosol optical depth at $550 \mathrm{~nm}$ as estimated from paintings and model calculations. (b) The corresponding Dust Veil Index. The numbers on the DVI histogram refer to the same major volcanic eruptions outlined in Fig. 2.

bias discussed in the previous paragraph. The estimate of the aerosol optical depth was done by converting the R/G measurements on paintings at a given solar zenith angle through the nomogram of Fig. 4 to optical depth at $550 \mathrm{~nm}$. At the paintings where the sun was under the horizon and the calculation of the solar zenith angle was not possible, we hypothesized it to be $100^{\circ}$.

Figure 5a shows the time series of the aerosol optical depth from all paintings using the method described above along with the time series of DVI for the 400-year period 1500 1900. The estimated aerosol optical depth ranged from 0.05 for background aerosol conditions at middle latitudes of the northern hemisphere, up to 0.6 which corresponds to the Tambora eruption. The numbers on the DVI histogram refer to the same major volcanic eruptions outlined in Fig. 2. Table 1 summarizes the aerosol optical depth as estimated in this study from paintings which is found to be in reasonable agreement with independent estimates by other authors. Robock and Free (1996) estimated that the aerosol optical depth for Laki has a value of 0.19 while Robertson et al. (2001) give 0.16. Both papers (Robertson et al., 2001; Robock and Free, 1996) give to Tambora the value of 0.50 , while Stothers (1984b) calculated the global optical depth to be 0.85 in $1815,0.9$ in 1816 and 0.2 in 1817 . For 1831 and 1835 Robock and Free (1996) estimated an optical depth of 0.09 and 0.11 and Robertson et al. (2001) of 0.07 and 0.18 respectively. For the Krakatau eruption, Sato et al. (1993) estimated the optical depth to be about 0.13, Stothers (1996) gives 0.14 in 1884 decreasing to 0.02 by 1886 , Robock and Free (1996) give 0.12 and Robertson et al. (2001) 0.09, while Dermidijian (1973) estimates an AOD of about 0.6. As seen in Fig. 6 the correlation coefficient between AOD and DVI is 0.87 again remarkably significant and points out to the important information that can be extracted from paintings portaging natural phenomena, which attracted the attention of famous painters, although probably most of them did not know anything about their occurrence. 
Table 2. Error in AOD estimates derived from the average R/G variability within a painting $( \pm 0.014$ according to table $A 1)$.

\begin{tabular}{lll}
\hline Solar Zenith angle & AOD & Error \\
\hline \multirow{2}{*}{75} & 0.1 & $<0.05$ \\
& 0.5 & 0.06 to 0.12 \\
85 & 0.1 & $<0.05$ \\
& 0.5 & 0.1 to 0.18 \\
\hline
\end{tabular}

\subsection{Error sources and uncertainties of the AOD estimates}

There are many sources of uncertainties both in the experimental determination of the $\mathrm{R} / \mathrm{G}$ ratios as well as in the model calculations, which both affect the accuracy of the AOD estimates. Concerning the extraction of the R/G ratios from digital images of paintings the following sources of uncertainty can be identified: The use of different cameras, the use of flash or natural light, different exposure times between different shots may produce different digital versions for the same painting. In order to make an estimate how these different techniques might affect the measured $R / G$ ratios in a digital image, we conducted a simple experiment where we photographed the same sunset image with two different digital cameras, using natural light and different exposure times. Then these images were analysed in a similar manner as the paintings.

The resulted differences in the $\mathrm{R} / \mathrm{G}$ ratios were very small (less than 0.01 ) and smaller than the variability of the $\mathrm{R} / \mathrm{G}$ within the digital image. We note here however, that the remarkable high correlation found between the $\mathrm{R} / \mathrm{G}$ ratios and the DVI strongly indicate that such possible small uncertainties might cancel out when we consider ratios obtained with different cameras, since use of flashes is not applicable in digital photos of paintings. Other source of uncertainty in the $R / G$ values is their variability within a painting/image, which also largely depends on the area selected to measure on the painting. According to table A1 (see Appendix A) this variability is the order of 0.014 (mean error value). This range of uncertainty in the determination of $\mathrm{R} / \mathrm{G}$ affects also our ability to retrieve from these ratios estimates of AOD. Tables 2 and 3 show the expected uncertainty in the estimated AOD due to the variability of the $\mathrm{R} / \mathrm{G}$ ratios within a painting and to uncertainties in determining the SZA. These errors are given for different AOD and SZA values. The uncertainty is less than 0.05 for small optical depths and smaller SZA. This number is comparable to the accuracy of other experiment measurements of AOD. The error however increases with increasing AOD and SZA and can be as large as 0.18 for AOD larger than 0.5 .

Our model estimates of the $\mathrm{R} / \mathrm{G}$ ratios are approximations and include systematic sources of errors or bias. There are mainly two sources of systematic bias in our calculations.

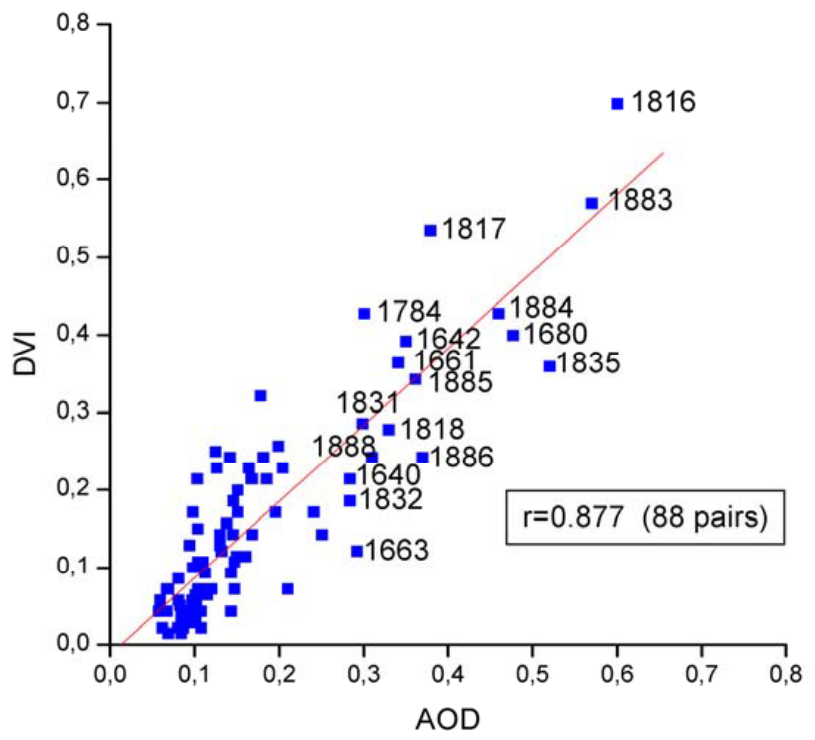

Fig. 6. Linear correlation between annual mean aerosol optical depth at $550 \mathrm{~nm}$, estimated from sunset paintings following volcanic eruptions, and mean annual values of DVI. The errors in the AOD are less than 0.05 for values around 0.1 and can be up to 0.18 for AOD values greater then 0.5 .

Table 3. Error in AOD derived from a typical error in estimating the SZA in a painting within $\pm 2^{\circ}$.

\begin{tabular}{lll}
\hline Solar Zenith angle & AOD & Error \\
\hline \multirow{2}{*}{75} & 0.1 & $<0.05$ \\
& 0.5 & 0.07 \\
85 & 0.1 & $<0.05$ \\
& 0.5 & $<0.05$ \\
\hline
\end{tabular}

The first concerns the use of RGB values directly calculated from the libRadtran model using the CIE color matching functions (Mayer and Emde, 2007). These R/G ratios are systematically higher (about 0.1 ) than those calculated from the ratio of two wavelengths for SZAs smaller than $85 \mathrm{deg}$. Another source of systematic bias is the type of radiometric calculations performed. In our calculations we used the diffuse irradiance over the whole hemisphere at the given wavelengths. However if we calculate the $R / G$ ratios shown in Figs. 1 and 2 using the integral of the calculated radiances within $20^{\circ}$ azimuth, around the setting sun and for zenith angles 70-90deg, then we would be able to simulate with the model the paintings' ratios even better. We note here that the radiative transfer solver included in libRadtran is only a pseudo-spherical and not a fully spherical code, and therefore its accuracy for radiance calculations is limited at high SZAs. The values based on the radiance calculations are considerably higher (20-30\%) than those shown in Fig. 3, both for 
volcanic and non volcanic conditions. For high AOD values $(>0.5)$ the results from the model and the paintings are very close and thus most of the bias is eliminated when one uses the radiances for the calculation of the $R / G$ ratios. However we did not extend our sensitivity tests for higher zenith angles since the usefulness of radiance values for the retrieval is determined by the increased uncertainty of the 1-D radiative transfer model for high solar zenith angles.

\section{Conclusions}

In this work we have attempted to estimate the aerosol optical depth following major volcanic eruptions as well as to provide evidence of the variability of the background atmospheric optical depth at $550 \mathrm{~nm}$ in a 400 -year period, estimated from the coloration of sunsets in famous art paintings. These reconstructed AOD timeseries provide the advantage, compared to DVI and other indices, that they can be directly used in models for radiative forcing calculations for periods with no measurements available. The reconstructed data can be compared with current (20th century) measurements of AOD, to provide estimates of long-term variability of background AOD during a period of about 500 years. These estimates can be useful to detect changes related to air pollution over Europe's middle latitudes.

The results presented show a strong dependence of the chromatic $\mathrm{R} / \mathrm{G}$ ratios perception by the painters on the scattering state of the atmosphere. The artists for the 400-year period under study (1500-1900) appear to have simulated the colours of nature with a remarkable precise coloration as proved by the unexpected high correlation coefficient of 0.83 found between the well known index of volcanic activity (DVI) and the values of the coloration depicted in the sunset paintings. A time series of aerosol optical depth at $550 \mathrm{~nm}$ has been compiled, representing the middle latitudes of the Northern Hemisphere and covers the periods 15001900. The aerosol optical depth estimated ranged from 0.05 , for background aerosol conditions, up to about 0.6 which corresponded to the period after the Tambora and Krakatau eruptions. These estimates are in reasonable agreement with independent studies referring to the same period. We should note here that because of the controversy on the date that the famous painting "The Scream" was created by Edvard Munch prevented us to use it as sample. This is because while Robock (2000) attributes it to the 1892 Awu eruption, Olson (2004) shows topographically that it was created about ten years before, in the winter of 1883-84. The high $\mathrm{R} / \mathrm{G}$ value of "The Scream" (over 2.10), as well as similar high values of other paintings by Edvard Munch (e.g. "Despair" and "Anxiety") are possible indications illustrating the memory kept by the painter of the coloration of the optical phenomena which he saw following the 1883 Krakatau event.

At any rate, we believe that this study will form the basis for more research to be done on environmental information content in art paintings. Through the eyes of painters and other artists it is expected to get information on past natural phenomena that have escaped attention of scholars until now. As J. M. W. Turner (Bockemuhl, 2000) said: “I did not paint it to be understood, but I wished to show what such a scene was like".

\section{Appendix A}

\section{Examples of "volcanic" and "non-volcanic" paintings considered in the paper}

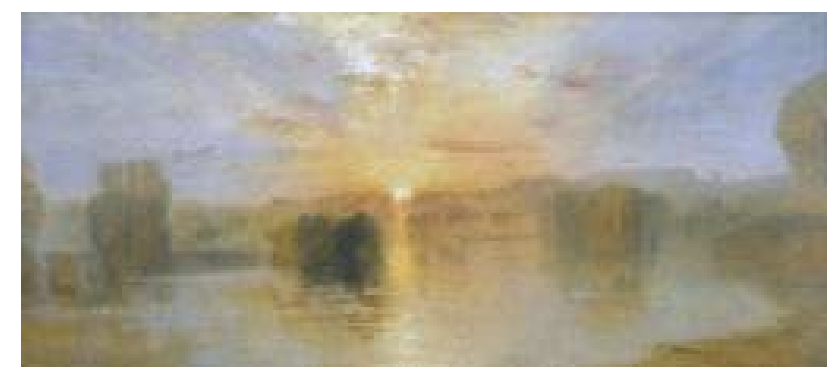

Fig. A1. Example of a non-volcanic sunset, painted by J.M.W Turner entitled "The Lake, Petworth, Sunset", created in 1828, with $\mathrm{R} / \mathrm{G}$ ratio of $1.14 \pm 0.04$ (see Tate Gallery at http://www.tate.org.uk/ servlet/ViewWork?cgroupid=999999996 $\backslash \backslash \&\}$ workid=14876).

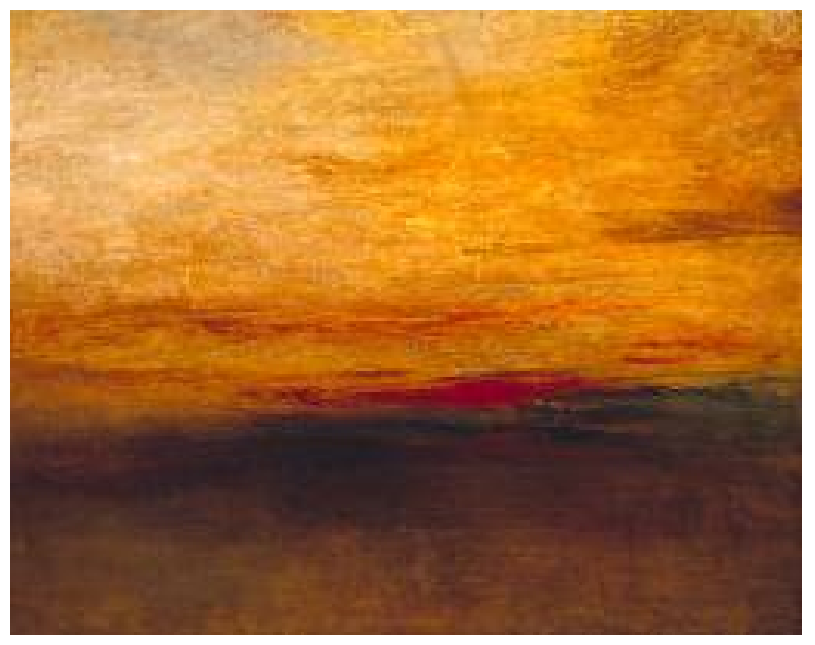

Fig. A2. Example of volcanic sunset by J. M. W. Turner entitled "Sunset" (c.1833) with R/G ratio of $1.76 \pm 0.03$, that illustrate the optical phenomena due to the eruption of Babuyan (1831) (see Tate Gallery at http://www.tate.org.uk/servlet/ViewWork? cgroupid=999999996 $\backslash \backslash \&\}$ workid=14820). 


\section{Appendix B}

\section{Art paintings and measured R/G values}

Table B1. Prospective users of AOD values are kindly requested to contact zerefos@ geol.uoa.gr prior to any use.

\begin{tabular}{|c|c|c|c|c|c|c|}
\hline Painter's Name & Title of Painting & Year & $\mathrm{R} / \mathrm{G}$ & SZA & AOD & Gallery* \\
\hline Gerard David & God the Father Blessing & 1506 & $1.16 \pm 0.01$ & 999 & 0.1 & LVR \\
\hline Tiziano Vecellio & Girl with a Basket of Fruits & 1557 & $1.31 \pm 0.03$ & 95 & 0.15 & STL \\
\hline Jan Brueghel the Elder & Landscape with Windmills & 1607 & $1.22 \pm 0.05$ & 999 & 0.12 & PRD \\
\hline Peter Paul Rubens & The Four Philosophers & 1612 & $1.06 \pm 0.02$ & 999 & 0.07 & PLP \\
\hline Hendrick Terbrugghen & $\begin{array}{l}\text { St Sebastian Tended by Irene and her } \\
\text { Maid }\end{array}$ & 1625 & $1.24 \pm 0.03$ & 100 & 0.12 & AMA \\
\hline Sir Anthony van Dyck & Portrait of the Painter Cornelis de Wae & 1627 & $1.22 \pm 0.01$ & 999 & 0.12 & RBA \\
\hline Rembrandt & $\begin{array}{l}\text { The Risen Christ Appearing to Mary } \\
\text { Magdalen }\end{array}$ & 1638 & $1.03 \pm 0.02$ & 85 & 0.06 & RCL \\
\hline Gellee, Claude (Le Lorrain) & Imaginary View of Tivoli & 1642 & $1.49 \pm 0.06$ & 85 & 0.36 & CTI \\
\hline Gellee, Claude (Le Lorrain) & Italian Coastal Landscape & 1642 & $1.38 \pm 0.09$ & 83 & 0.37 & STL \\
\hline Nicolaes Pietersz Berchem & Landscape with Jacob, Rachel, and Leah & 1643 & $1.13 \pm 0.02$ & 86 & 0.14 & LVR \\
\hline Gellee, Claude (Le Lorrain) & Harbour Scene at Sunset & 1643 & $1.17 \pm 0.02$ & 87 & 0.17 & RCL \\
\hline Gellee, Claude (Le Lorrain) & Landscape with Paris and Oenone & 1648 & $1.13 \pm 0.01$ & 82 & 0.09 & LVR \\
\hline Gellee, Claude (Le Lorrain) & $\begin{array}{l}\text { Seaport with the Embarkation of the } \\
\text { Queen of Sheba }\end{array}$ & 1648 & $1.14 \pm 0.03$ & 85 & 0.09 & NGL \\
\hline Gellee, Claude (Le Lorrain) & Ulysses Returns Chryseis to her Father & 1648 & $1.16 \pm 0.02$ & 82 & 0.09 & LVR \\
\hline Jacob Adriaensz Backer & Venus and Adonis & 1650 & $1.41 \pm 0.04$ & 999 & 0.18 & SFS \\
\hline Cuyp Aelbert & Herdsman with Cows by a River & 1650 & $1.05 \pm 0.00$ & 71 & 0.17 & NGL \\
\hline David Teniers the Younger & Flemish Kermess & 1652 & $1.19 \pm 0.04$ & 92 & 0.1 & RBA \\
\hline Gellee, Claude (Le Lorrain) & $\begin{array}{l}\text { Landscape with the Rest on the Flight into } \\
\text { Egypt }\end{array}$ & 1661 & $1.21 \pm 0.01$ & 80 & 0.34 & HMT \\
\hline Jan de Bray & $\begin{array}{l}\text { Pharaoh's Daughter with Her Attendants } \\
\text { and Moses in the Reed Basket }\end{array}$ & 1661 & $1.52 \pm 0.04$ & 999 & 0.28 & $\mathrm{BVB}$ \\
\hline Gellee, Claude (Le Lorrain) & Landscape with Tobias and the Angel & 1663 & $1.48 \pm 0.02$ & 84 & 0.29 & HMT \\
\hline Ludolf Backhuysen & Ships in Distress off a Rocky Coast & 1667 & $1.17 \pm 0.02$ & 69 & 0.23 & NGA \\
\hline Wright John Michael & Sir Neil O’Neill & 1680 & $1.71 \pm 0.04$ & 93 & 0.47 & NGA \\
\hline Jacob de Heusch & River View with the Ponte Rotto & 1696 & $1.15 \pm 0.02$ & 66 & 999 & HAU \\
\hline Louis Philippe Boitard & $\begin{array}{l}\text { An Exact Representation of the Game } \\
\text { Cricket }\end{array}$ & 1760 & $1.21 \pm 0.02$ & 999 & 0.11 & TTG \\
\hline James Lambert & Landscape & 1769 & $1.14 \pm 0.01$ & 90 & 0.09 & NGL \\
\hline John Singleton Copley & Watson and the Shark & 1778 & $1.07 \pm 0.04$ & 65 & 999 & FAB \\
\hline De Loutherbourg, Philip James & Travellers Attacked by Banditti & 1781 & $1.10 \pm 0.01$ & 69 & 999 & TTG \\
\hline Jakob Philipp Hackert & Landscape with a Ancient Festival & 1781 & $1.11 \pm 001$ & 76 & 0.2 & HMT \\
\hline Thomas Gainsborough & Girl with Pigs & 1782 & $1.23 \pm 0.02$ & 999 & 0.13 & $\mathrm{CHW}$ \\
\hline John Singleton Copley & Mrs. Daniel Denison Rogers & 1784 & $1.66 \pm 0.16$ & 86 & 0.32 & FGA \\
\hline Jakob Philipp Hackert & View of Caserta & 1784 & $1.09 \pm 0.01$ & 55 & 999 & HMT \\
\hline Sir Joshua Reynolds & Lady Elizabeth Foster & 1787 & $1.70 \pm 0.03$ & 100 & 0.27 & TTG \\
\hline Jakob Philipp Hackert & Italian Landscape & 1795 & $1.14 \pm 0.04$ & 76 & 0.25 & HMT \\
\hline Joseph Mallord William Turner & $\begin{array}{l}\text { A Road Crossing a River; Sunset Sky } \\
\text { Seen beyond Trees }\end{array}$ & 1798 & $1.11 \pm 0.02$ & 82 & 0.08 & TTG \\
\hline Jean Broc & The Death of Hyacinth & 1801 & $1.08 \pm 0.01$ & 90 & 0.07 & $\mathrm{RPC}$ \\
\hline Joseph Mallord William Turner & $\begin{array}{l}\text { Distant View of Whitby from the Moors: } \\
\text { A Windmill against a Sunset Sky; The } \\
\text { Abbey Beyond }\end{array}$ & 1801 & $1.07 \pm 0.02$ & 86 & 0.07 & TTG \\
\hline Joseph Anton von Koch & $\begin{array}{l}\text { The Monastery of San Francesco di } \\
\text { Civitella in the Sabine Mountains }\end{array}$ & 1812 & $1.29 \pm 0.03$ & 90 & 0.19 & HMT \\
\hline
\end{tabular}


Table B1. Continued.

\begin{tabular}{|c|c|c|c|c|c|c|}
\hline Painter's Name & Title of Painting & Year & $\mathrm{R} / \mathrm{G}$ & SZA & AOD & Gallery* \\
\hline Karl Friedrich Schinkel & The Banks of the Spree near Stralau & 1817 & $1.29 \pm 0.01$ & 90 & 0.19 & NGB \\
\hline Caspar David Friedrich & Griefswald in the Moonlight & 1817 & $1.12 \pm 0.05$ & 100 & 0.14 & NGO \\
\hline Joseph Mallord William Turner & The Decline of the Carthaginian Empire & 1817 & $1.27 \pm 0.03$ & 74 & 0.46 & TTG \\
\hline Caspar David Friedrich & Two Men by the Sea at Moonrise & 1817 & $1.26 \pm 0.14$ & 100 & 0.19 & NGB \\
\hline Theodore Gericault & Landscape with Acqueduct & 1818 & $1.23 \pm 0.00$ & 81 & 0.36 & MMA \\
\hline Caspar David Friedrich & Woman in front of the Setting Sun & 1818 & $1.64 \pm 0.09$ & 92 & 0.32 & FLK \\
\hline Caspar David Friedrich & Wanderer Looking over the Sea of Fog & 1818 & $1.11 \pm 0.00$ & 999 & 0.14 & $\mathrm{KNH}$ \\
\hline Joseph Mallord William Turner & $\begin{array}{l}\text { The Roman Campagna from Monte Tes- } \\
\text { taccio, Sunset }\end{array}$ & 1819 & $1.05 \pm 0.01$ & 76 & 0.23 & TTG \\
\hline Joseph Mallord William Turner & Moonlight over the Campagna & 1819 & $1.06 \pm 0.01$ & 999 & 0.07 & TTG \\
\hline Joseph Mallord William Turner & St. Peter's from the South & 1819 & $1.38 \pm 0.02$ & 78 & 0.17 & BRN \\
\hline Nasmyth Patrick & View near Sevenoaks, Kent & 1820 & $1.03 \pm 0.02$ & 82 & 0.09 & NGA \\
\hline Richard Parkes Bonington & Landscape, Sunset & 1826 & $1.06 \pm 0.01$ & 65 & 0.07 & TAS \\
\hline Joseph Mallord William Turner & Evening: A Windmill at Sunset & 1827 & $1.17 \pm 0.04$ & 92 & 0.1 & TTG \\
\hline Joseph Mallord William Turner & The Setting Sun over Petworth Park & 1827 & $1.20 \pm 0.03$ & 95 & 0.11 & TTG \\
\hline Joseph Mallord William Turner & $\begin{array}{l}\text { Petworth Park; Sunset ('Glade and } \\
\text { Greensward') }\end{array}$ & 1827 & $1.18 \pm 0.01$ & 100 & 0.1 & TTG \\
\hline Joseph Mallord William Turner & Setting Sun & 1827 & $1.19 \pm 0.01$ & 88 & 0.12 & TTG \\
\hline Joseph Mallord William Turner & $\begin{array}{l}\text { Sunset across the Park from the Terrace of } \\
\text { Petworth House }\end{array}$ & 1827 & $1.21 \pm 0.04$ & 89 & 0.12 & TTG \\
\hline Joseph Mallord William Turner & $\begin{array}{l}\text { Sunset over the Ridge Seen from the } \\
\text { North Pond in Petworth Park }\end{array}$ & 1827 & $1.01 \pm 0.01$ & 100 & 0.06 & TTG \\
\hline Joseph Mallord William Turner & $\begin{array}{l}\text { Evening: A Boat on a River with a Distant } \\
\text { Tower }\end{array}$ & 1827 & $1.15 \pm 0.02$ & 100 & 0.09 & TTG \\
\hline Joseph Mallord William Turner & Sunset: A Boat on a River & 1827 & $1.22 \pm 002$ & 87 & 0.12 & TTG \\
\hline Richard Parkes Bonington & Sunset in the Pays de Caux & 1828 & $1.07 \pm 0.03$ & 79 & 0.07 & WLC \\
\hline Joseph Mallord William Turner & Claudian Harbour Scene & 1828 & $1.17 \pm 0.00$ & 95 & 0.1 & TTG \\
\hline Joseph Mallord William Turner & Cilgerran Castle, Pembrokeshire & 1828 & $1.08 \pm 0.01$ & 100 & 0.08 & TTG \\
\hline Dawe George & $\begin{array}{l}\text { Portrait of Fieldmarshal Mikhail Barclay } \\
\text { de Tolly }\end{array}$ & 1829 & $1.30 \pm 0.04$ & 87 & 0.15 & HMT \\
\hline Ferdinand Olivier & Elijah in the Wilderness & 1831 & $1.14 \pm 0.00$ & 61 & 999 & NPM \\
\hline Joseph Mallord William Turner & Fort Vimieux & 1831 & $1.73 \pm 0.12$ & 87 & 0.4 & PRV \\
\hline Joseph Mallord William Turner & Le Havre: Sunset in the Port & 1832 & $1.02 \pm 0.01$ & 73 & 0.27 & TTG \\
\hline Caspar David Friedrich & Swans in the Reeds & 1832 & $1.66 \pm 0.06$ & 90 & 0.31 & HMT \\
\hline Caspar David Friedrich & The Stages of Life & 1835 & $1.11 \pm 0.05$ & 85 & 0.08 & MBK \\
\hline Khrutsky Ivan & Young Woman with Basket & 1835 & $1.16 \pm 0.01$ & 90 & 0.09 & HMT \\
\hline Caspar David Friedrich & The Dreamer (Ruins of the Oybin) & 1835 & $1.70 \pm 0.08$ & 90 & 0.52 & HMT \\
\hline Thomson, Rev. John, of Duddingston & $\begin{array}{l}\text { Loch-an-Eilean, } \quad \text { Rothiemurchus, } \\
\text { Inverness-shire }\end{array}$ & 1835 & $1.80 \pm 0.02$ & 999 & 0.36 & NGA \\
\hline Hagen, August Mathias & Sea Bay & 1835 & $1.21 \pm 0.02$ & 100 & 0.17 & HMT \\
\hline Joseph Mallord William Turner & Flint Castle & 1838 & $1.11 \pm 0.02$ & 90 & 0.08 & PRV \\
\hline Jean-Baptiste-Camille Corot & Landscape with Lake and Boatman & 1839 & $1.30 \pm 0.11$ & 100 & 0.15 & GTT \\
\hline Joseph Mallord William Turner & Dinant, on the Meuse, from the South & 1839 & $1.03 \pm 0.01$ & 999 & 0.07 & TTG \\
\hline Khrutsky Ivan & View on Yelagin Island in St. Petersburg & 1839 & $1.21 \pm 0.05$ & 63 & 999 & HMT \\
\hline Joseph Mallord William Turner & Mayen in the Eifel & 1839 & $1.09 \pm 0.01$ & 999 & 0.07 & TTG \\
\hline Joseph Mallord William Turner & A View of Metz from the North & c. 1839 & $1.28 \pm 0.04$ & 100 & 0.14 & TTG \\
\hline Christina Robertson & $\begin{array}{l}\text { Portrait of Grand Princess Alexandra } \\
\text { Nikolayevna }\end{array}$ & 1840 & $1.11 \pm 0.01$ & 999 & 0.08 & HMT \\
\hline Joseph Mallord William Turner & $\begin{array}{l}\text { Distant View of Regensburg from the } \\
\text { Dreifaltigkeitsberg }\end{array}$ & 1840 & $1.06 \pm 0.00$ & 86 & 0.07 & TTG \\
\hline Joseph Mallord William Turner & Sunset on a Lake & 1841 & $1.16 \pm 0.01$ & 999 & 0.09 & TTG \\
\hline Joseph Mallord William Turner & Mont Pilatus: Sunset & 1841 & $1.08 \pm 0.01$ & 85 & 0.07 & TTG \\
\hline Joseph Mallord William Turner & $\begin{array}{l}\text { Geneva, the Jura Mountains and Isle } \\
\text { Rousseau, Sunset }\end{array}$ & 1841 & $1.13 \pm 0.02$ & 85 & 0.09 & TTG \\
\hline
\end{tabular}


Table B1. Continued.

\begin{tabular}{|c|c|c|c|c|c|c|}
\hline Painter's Name & Title of Painting & Year & $\mathrm{R} / \mathrm{G}$ & SZA & AOD & Gallery* \\
\hline Joseph Mallord William Turner & Sunset, Lake of Lucerne & 1841 & $1.12 \pm 0.01$ & 66 & 999 & TTG \\
\hline Charles-Gabriel Gleyre & Evening or Lost Illusions & 1843 & $1.16 \pm 0.04$ & 83 & 0.1 & KNM \\
\hline Joseph Mallord William Turner & Yellow Sun over Water & 1845 & $1.21 \pm 0.05$ & 90 & 0.12 & TTG \\
\hline Alexander Ivanov & Via Appia & 1845 & $1.07 \pm 0.01$ & 66 & 999 & TRV \\
\hline Joseph Mallord William Turner & Sunset, over the Water & 1845 & $1.28 \pm 0.02$ & 90 & 0.14 & TTG \\
\hline Eugène Delacroix & Study of Sky Setting Sun & 1849 & $1.19 \pm 0.08$ & 88 & 0.11 & LVR \\
\hline Fitz Hugh Lane & $\begin{array}{l}\text { Camden Mountains From the South En- } \\
\text { trance to the Harbor }\end{array}$ & 1859 & $1.14 \pm 0.01$ & 87 & 0.09 & FRW \\
\hline Fitz Hugh Lane & Boston Harbor & $1850-52$ & $1.11 \pm 0.02$ & 86 & 0.08 & FAB \\
\hline Gifford Sanford Robinson & Mansfield Mountain & 1859 & $1.10 \pm 0.02$ & 82 & 0.08 & MNG \\
\hline Albert Bierstadt & Coastal View, Newport & 1861 & $1.10 \pm 0.00$ & 90 & 0.08 & PRV \\
\hline Gifford Sanford Robinson & A twilight in the Catskills & 1861 & $1.28 \pm 0.01$ & 95 & 0.14 & PRV \\
\hline Albert Bierstadt & Indian Summer - Hudson River & 1861 & $1.10 \pm 0.02$ & 82 & 0.08 & PRV \\
\hline Gifford Sanford Robinson & A twilight in Adrindacks & 1861 & $1.20 \pm 0.01$ & 100 & 0.11 & PRV \\
\hline Gifford Sanford Robinson & A Lake Twilight & 1861 & $1.04 \pm 0.01$ & 90 & 0.07 & PRV \\
\hline Perov Vasily & The Last Tavern at the City Gates & 1868 & $1.14 \pm 0.04$ & 95 & 0.09 & TRV \\
\hline Eugene Fromentin & Desert Scene & 1868 & $1.32 \pm 0.07$ & 999 & 0.16 & HMT \\
\hline Jean-Leon Gerome & Excursion of the Harem & 1869 & $1.27 \pm 0.11$ & 67 & 999 & $\mathrm{CHR}$ \\
\hline Albert Bierstadt & Sunset in Yosemite Valley & 1869 & $1.38 \pm 0.07$ & 87 & 0.17 & HGG \\
\hline Gifford Sanford Robinson & An October Afternoon & 1871 & $1.09 \pm 0.01$ & 68 & 999 & FAB \\
\hline Edgar Degas & Horses in a Meadow & 1871 & $1.05 \pm 0.01$ & 999 & 0.07 & NGA \\
\hline Albert Bierstadt & El Capitan, Yosemite Valley & 1875 & $1.02 \pm 0.00$ & 64 & 999 & TLD \\
\hline Jasper Francis Cropsey & Deer by a Mountain Lake & 1875 & $1.37 \pm 0.02$ & 90 & 0.17 & PRV \\
\hline Jasper Francis Cropsey & $\begin{array}{l}\text { Autumn Landscape with Boaters on a } \\
\text { Lake }\end{array}$ & 1875 & $1.13 \pm 0.11$ & 82 & 0.11 & $\mathrm{NCF}$ \\
\hline Gifford Sanford Robinson & A Sunset, Bay of New York & 1878 & $1.29 \pm 0.08$ & 85 & 0.14 & EVR \\
\hline Gifford Sanford Robinson & $\begin{array}{l}\text { Sunset on the Shore of No Man's Land- } \\
\text { Bass Fishing }\end{array}$ & 1878 & $1.05 \pm 0.00$ & 86 & 0.07 & PRV \\
\hline Gustav Klimt & Fable & 1883 & $1.12 \pm 0.02$ & 92 & 0.09 & $\mathrm{HCV}$ \\
\hline Pierre-Auguste Renoir & Seating Girl & 1883 & $1.28 \pm 0.06$ & 999 & 0.15 & PRV \\
\hline William Ascroft & Twilight and Afterglow Effects & 1883 & $2.02 \pm 0.05$ & 101.6 & 0.57 & $\mathrm{SCN}$ \\
\hline William Ascroft & Twilight and Afterglow Effects & 1884 & $2.04 \pm 0.06$ & 92 & 0.46 & $\mathrm{SCN}$ \\
\hline Breton Jules & The Song of the Lark & 1884 & $1.74 \pm 0.05$ & 89 & 0.35 & AIC \\
\hline William Ascroft & Twilight and Afterglow Effects & 1885 & $1.75 \pm 0.05$ & 97 & 0.36 & $\mathrm{SCN}$ \\
\hline Albert Pinkham Ryder & The Temple of the Mind & 1885 & $1.75 \pm 0.16$ & 86 & 0.36 & PRV \\
\hline John Atkinson Grimshaw & An Autumn Idyll & 1885 & $1.28 \pm 0.07$ & 90 & 0.18 & RCA \\
\hline Jasper Francis Cropsey & Evening on the Hudson & 1885 & $1.32 \pm 0.08$ & 88 & 0.2 & $\mathrm{NCF}$ \\
\hline William Ascroft & Twilight and Afterglow Effects & 1886 & $1.81 \pm 0.03$ & 96 & 0.37 & $\mathrm{SCN}$ \\
\hline Yelland Raymond & Moonrise Over Seacoast at Pacific Grove & 1886 & $1.75 \pm 0.04$ & 100 & 0.33 & OKL \\
\hline Garstin Norman & Haycocks and Sun & 1886 & $1.12 \pm 0.02$ & 86 & 0.13 & TTG \\
\hline Jasper Francis Cropsey & Palisades At Sunset & 1887 & $1.12 \pm 0.03$ & 89 & 0.08 & $\mathrm{NCF}$ \\
\hline Jasper Francis Cropsey & View From Artist's Residence, Sunset & 1887 & $1.17 \pm 0.03$ & 82 & 0.1 & $\mathrm{NCF}$ \\
\hline Warren W. Sheppard & Moonlight Sail off the Highlands & 1888 & $1.78 \pm 0.05$ & 100 & 0.29 & PRV \\
\hline Millais Sir John Everett & The Moon is Up, and Yet it is not Night & 1890 & $1.24 \pm 0.01$ & 999 & 0.13 & NGA \\
\hline Thomas Hope McLachlan & Evening Quiet & 1891 & $1.30 \pm 0.01$ & 999 & 0.15 & TTG \\
\hline Edgar Degas & Weatfield and Green Hill & 1892 & $1.21 \pm 0.01$ & 82 & 0.12 & NSM \\
\hline Ralph Albert Blakelock & Moonlight & $1885-89$ & $1.17 \pm 0.03$ & 100 & 0.09 & BKL \\
\hline Heironymous Bosch & The Path of Life & $1500-02$ & $1.13 \pm 0.01$ & 81 & 0.10 & LVR \\
\hline Lambert Sustris & Jupiter and Io & $1557-63$ & $1.12 \pm 0.01$ & 999 & 0.09 & HMT \\
\hline Peter Paul Rubens & The Capture of Juliers & $1621-25$ & $1.04 \pm 0.02$ & 85 & 0.07 & LVR \\
\hline Gellee, Claude (Le Lorrain) & Embarkation of St Paula Romana at Ostia & $1637-39$ & $1.03 \pm 0.02$ & 79 & 0.1 & PRD \\
\hline Jacques Stella & Minerva and the Muses & $1640-45$ & $1.11 \pm 0.01$ & 999 & 0.08 & LVR \\
\hline Gellee, Claude (Le Lorrain) & $\begin{array}{l}\text { The Disembarkation of Cleopatra at Tar- } \\
\text { sus }\end{array}$ & $1642-43$ & $1.15 \pm 0.02$ & 80 & 0.27 & LVR \\
\hline
\end{tabular}


Table B1. Continued.

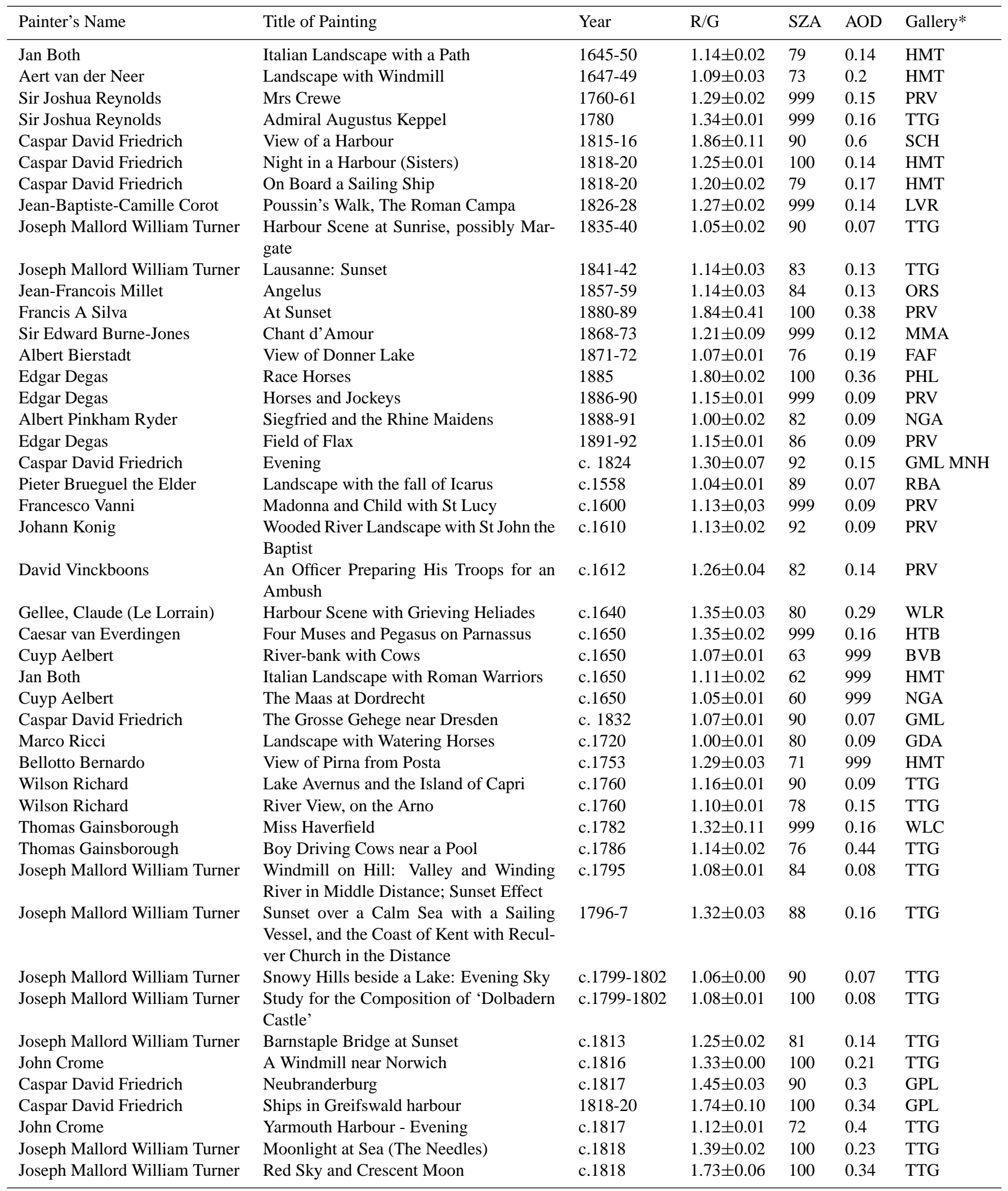


Table B1. Continued.

\begin{tabular}{|c|c|c|c|c|c|c|}
\hline Painter's Name & Title of Painting & Year & $\mathrm{R} / \mathrm{G}$ & SZA & AOD & Gallery* \\
\hline Caspar David Friedrich & The Sisters on the Balcony & c. 1820 & $1.39 \pm 0.12$ & 100 & 0.18 & HMT \\
\hline Joseph Mallord William Turner & The Bass Rock & c. 1824 & $1.20 \pm 0.07$ & 87 & 0.11 & TTG \\
\hline Joseph Mallord William Turner & Crimson Sunset & c. 1825 & $1.28 \pm 0.06$ & 90 & 0.14 & TTG \\
\hline Joseph Mallord William Turner & Fiery Sunset & c. $1825-27$ & $1.23 \pm 0.04$ & 100 & 0.12 & TTG \\
\hline Joseph Mallord William Turner & Sunset over Water & c. $1825-27$ & $1.30 \pm 0.02$ & 81 & 0.22 & TTG \\
\hline Joseph Mallord William Turner & Gloucester Cathedral & c. 1826 & $1.15 \pm 0.01$ & 100 & 0.1 & TTG \\
\hline Joseph Mallord William Turner & $\begin{array}{l}\text { A Distant View of the Upperton Monu- } \\
\text { ment, from the Lake in Petworth Park }\end{array}$ & c. 1827 & $1.21 \pm 0.04$ & 100 & 0.12 & TTG \\
\hline Joseph Mallord William Turner & Ariccia (?): Sunset & c. 1828 & $1.04 \pm 0.01$ & 85 & 0.06 & TTG \\
\hline Joseph Mallord William Turner & The Lake, Petworth, Sunset & c. 1828 & $1.12 \pm 0.02$ & 90 & 0.13 & TTG \\
\hline Joseph Mallord William Turner & A Ship Aground & c. 1828 & $1.04 \pm 0.02$ & 90 & 0.07 & TTG \\
\hline Joseph Mallord William Turner & The Chain Pier, Brighton & c. 1828 & $1.05 \pm 0.01$ & 84 & 0.07 & TTG \\
\hline Joseph Mallord William Turner & $\begin{array}{l}\text { Seacoast with Ruin, probably the Bay of } \\
\text { Baiae }\end{array}$ & c. 1828 & $1.17 \pm 0.01$ & 80 & 0.14 & TTG \\
\hline Joseph Mallord William Turner & $\begin{array}{l}\text { Petworth Park: Tillington Church in the } \\
\text { Distance }\end{array}$ & c. 1828 & $1.37 \pm 0.03$ & 100 & 0.17 & TTG \\
\hline Joseph Mallord William Turner & $\begin{array}{l}\text { St Michael's Mount from Marazion, } \\
\text { Cornwall }\end{array}$ & c. 1828 & $1.16 \pm 0.02$ & 84 & 0.09 & TTG \\
\hline Joseph Mallord William Turner & Chichester Canal & c. 1828 & $1.14 \pm 0.02$ & 90 & 0.09 & TTG \\
\hline Joseph Mallord William Turner & Classical Harbour Scene & c. 1828 & $1.07 \pm 0.00$ & 84 & 0.08 & TTG \\
\hline Joseph Mallord William Turner & $\begin{array}{l}\text { The Lake, Petworth: Sunset, Fighting } \\
\text { Bucks }\end{array}$ & c. 1829 & $1.29 \pm 0.04$ & 85 & 0.15 & TTG \\
\hline Joseph Mallord William Turner & $\begin{array}{l}\text { The Lake, Petworth: Sunset, a Stag } \\
\text { Drinking }\end{array}$ & c. 1829 & $1.35 \pm 0.02$ & 83 & 0.2 & TTG \\
\hline Joseph Mallord William Turner & Chichester Canal & c. 1829 & $1.30 \pm 0.02$ & 100 & 0.16 & TTG \\
\hline Joseph Mallord William Turner & Castle Upnor, Kent: Preparatory Study & c. $1829-30$ & $1.16 \pm 0.01$ & 72 & 999 & TTG \\
\hline Caspar David Friedrich & The Temple of Juno in Agrigent & c. 1830 & $1.31 \pm 0.08$ & 88 & 0.16 & MKK \\
\hline Joseph Mallord William Turner & $\begin{array}{l}\text { Sunset: Study for 'Flint Castle, on the } \\
\text { Welsh Coast' }\end{array}$ & c. 1830 & $1.15 \pm 0.01$ & 83 & 0.14 & TTG \\
\hline Joseph Mallord William Turner & Geneva & c. 1830 & $1.12 \pm 0.01$ & 86 & 0.09 & TTG \\
\hline Joseph Mallord William Turner & Datur Hora Quieti & c. $1831-32$ & $1.07 \pm 0.01$ & 90 & 0.08 & TTG \\
\hline Joseph Mallord William Turner & Tornaro (Roger's 'Poems) & c. 1832 & $1.08 \pm 0.00$ & 90 & 0.08 & TTG \\
\hline Joseph Mallord William Turner & A Town on a River at Sunset & c. 1833 & $1.07 \pm 0.00$ & 85 & 0.08 & TTG \\
\hline Joseph Mallord William Turner & Sunset & c. 1833 & $1.76 \pm 0.03$ & 100 & 0.35 & TTG \\
\hline Kroly Brocky & The Daughters of Istvn Medgyasszay & c. 1833 & $1.12 \pm 0.02$ & 999 & 0.09 & PRV \\
\hline Joseph Mallord William Turner & Sunset over Lake & c. 1834 & $1.23 \pm 0.01$ & 100 & 0.18 & TTG \\
\hline Joseph Mallord William Turner & Sunset & c. 1834 & $1.21 \pm 0.02$ & 88 & 0.17 & TTG \\
\hline Joseph Mallord William Turner & The Arch of Constantine, Rome & c. 1835 & $1.17 \pm 0.02$ & 70 & 999 & TTG \\
\hline Joseph Mallord William Turner & Tivoli: Tobias and the Angel & c. 1835 & $1.11 \pm 0.01$ & 83 & 0.09 & TTG \\
\hline Joseph Mallord William Turner & Sunset: A Fish Market on the Beach & c. 1835 & $1.07 \pm 0.01$ & 88 & 0.08 & TTG \\
\hline Joseph Mallord William Turner & View of Town, with Yellow Sky & c. 1839 & $1.07 \pm 0.01$ & 87 & 0.08 & TTG \\
\hline Joseph Mallord William Turner & Sunset on the Sea & c. 1839 & $1.14 \pm 0.01$ & 88 & 0.09 & TTG \\
\hline Joseph Mallord William Turner & Venice: Sunset & c. 1839 & $1.11 \pm 0.00$ & 100 & 0.09 & TTG \\
\hline Joseph Mallord William Turner & $\begin{array}{l}\text { Sunset, with Smoke from a Distant } \\
\text { Steamer }\end{array}$ & c. 1840 & $1.05 \pm 0.01$ & 75 & 0.19 & TTG \\
\hline Joseph Mallord William Turner & Sun Setting over a Lake & c. 1840 & $1.33 \pm 0.02$ & 89 & 0.16 & TTG \\
\hline Joseph Mallord William Turner & $\begin{array}{l}\text { Venice: The Campanile of S. Giorgio } \\
\text { Maggiore, with S. Maria della Salute on } \\
\text { the Right: Sunset }\end{array}$ & c. 1840 & $1.04 \pm 0.01$ & 72 & 999 & TTG \\
\hline Joseph Mallord William Turner & Sunset over Yellow-Green Waters & c. 1840 & $1.10 \pm 0.00$ & 88 & 0.09 & TTG \\
\hline Joseph Mallord William Turner & $\begin{array}{l}\text { S. Maria della Salute and the Dogana: } \\
\text { Sunset }\end{array}$ & c. 1840 & $1.06 \pm 0.00$ & 70 & 999 & TTG \\
\hline
\end{tabular}


Table B1. Continued.

\begin{tabular}{|c|c|c|c|c|c|c|}
\hline Painter's Name & Title of Painting & Year & $\mathrm{R} / \mathrm{G}$ & SZA & AOD & Gallery* \\
\hline Joseph Mallord William Turner & Orange Sunset & c. 1840 & $1.32 \pm 0.04$ & 85 & 0.16 & TTG \\
\hline Joseph Mallord William Turner & $\begin{array}{l}\text { The Walhalla, near Regensburg on the } \\
\text { Danube }\end{array}$ & c. $1840-42$ & $1.11 \pm 0.01$ & 90 & 0.09 & TTG \\
\hline Albert Bierstadt & Sunset, Deer, and River & c. 1868 & $1.39 \pm 0.02$ & 90 & 0.17 & PRV \\
\hline Edgar Degas & Eugene Manet & c. 1874 & 1.29 & 89 & 0.15 & PRV \\
\hline Albert Pinkham Ryder & With Sloping Mast and Dipping Prow & c. 1883 & $1.11 \pm 0.02$ & 100 & 0.08 & NAA \\
\hline Edgar Degas & Landscape on the Orne & c. 1884 & $1.22 \pm 0.04$ & 89 & 0.19 & PRV \\
\hline Elisha Taylor Baker & East river Scene, Brooklyn & c. 1886 & $1.75 \pm 0.04$ & 83 & 999 & PRV \\
\hline Edgar Degas & The Jockey & c. 1887 & $1.32 \pm 0.05$ & 90 & 0.16 & PHL \\
\hline Edgar Degas & Wheatfield and Line of Trees & c. $1890-93$ & $1.17 \pm 0.04$ & 88 & 0.1 & PRV \\
\hline Edgar Degas & Landscape: Cows in the Foreground & c. $1890-93$ & $1.13 \pm 0.01$ & 83 & 0.09 & PRV \\
\hline Edgar Degas & Landscape by the Sea & c. $1895-98$ & $1.12 \pm 0.01$ & 999 & 0.08 & PRV \\
\hline Edgar Degas & The Return of the Herd & c. $1896-98$ & $1.18 \pm 0.01$ & 72 & 999 & LCS \\
\hline Sebastien Bourdon & $\begin{array}{l}\text { Bacchus and Ceres with Nymphs and } \\
\text { Satyrs }\end{array}$ & $1640-60$ & $1.32 \pm 0.03$ & 999 & 0.16 & FAB \\
\hline Alonso Cano & The Dead Christ Supported by an Angel & $1646-52$ & $1.19 \pm 0.07$ & 90 & 0.11 & PRD \\
\hline Henry Anderton & $\begin{array}{l}\text { Mountain Landscape With dancing Shep- } \\
\text { herd }\end{array}$ & $1650-60$ & $1.28 \pm 0.02$ & 100 & 0.14 & TTG \\
\hline Francisco Camilo & Adoration of the Magi & $1660 \mathrm{~s}$ & $1.16 \pm 0.01$ & 100 & 0.09 & BAB \\
\hline Caesar van Everdingen & $\begin{array}{l}\text { Nymphs Offering the Young Bacchus } \\
\text { Wine, Fruit and Flowers }\end{array}$ & $1670-78$ & $1.31 \pm 0.02$ & 100 & 0.15 & $\mathrm{KDE}$ \\
\hline Luca Carlevaris & $\begin{array}{l}\text { The Sea Custom House with San Giorgio } \\
\text { Maggiore }\end{array}$ & $1700 \mathrm{~s}$ & $1.12 \pm 0.03$ & 97 & 0.09 & PRV \\
\hline Jan Weenix & Boar Hunt & $1703-16$ & $1.18 \pm 0.01$ & 999 & 0.1 & ALP \\
\hline John Crome & Moonrise on the Yare & 1811-16 & $1.40 \pm 0.01$ & 100 & 0.23 & TTG \\
\hline Joseph Mallord William Turner & Study of Sky & 1816-18 & $1.16 \pm 0.04$ & 69 & 999 & TTG \\
\hline Joseph Mallord William Turner & The River; Sunset & $1820-30$ & $1.07 \pm 0.01$ & 100 & 0.07 & TTG \\
\hline Joseph Mallord William Turner & Looking out to Sea & $1820-30$ & $1.09 \pm 0.00$ & 100 & 0.08 & TTG \\
\hline Joseph Mallord William Turner & Sunlight over Water & $1825-30$ & $1.12 \pm 0.01$ & 100 & 0.08 & TTG \\
\hline Joseph Mallord William Turner & The Scarlet Sunset & $1830-40$ & $2.40 \pm 0.17$ & 87 & 999 & TTG \\
\hline Alexander Ivanov & The Appearance of Christ to the People & $1837-57$ & $0.90 \pm 0.03$ & 100 & 0.03 & TRV \\
\hline Ziem, Felix Francois Georges Philibert & Harbour at Constantinople & $1880 \mathrm{~s}$ & $1.28 \pm 0.01$ & 87 & 0.14 & HMT \\
\hline Arkhip Kuinji & Sunset & $1885-90$ & $1.84 \pm 0.06$ & 999 & 0.31 & RSS \\
\hline Edgar Degas & Horses and Jockeys & $1886-90$ & $1.35 \pm 0.02$ & 80 & 0.17 & PRV \\
\hline Arkhip Kuinji & Sunset & $1890-95$ & $2.26 \pm 0.03$ & 88 & 999 & RSS \\
\hline Warren Sheppard & Sunset Sail & $1890 \mathrm{~s}$ & $1.21 \pm 0.03$ & 100 & 0.13 & SPF \\
\hline William Hogarth & $\begin{array}{l}\text { Conversation Piece (Portrait of Sir An- } \\
\text { drew Fountaine with Other Men and } \\
\text { Women) }\end{array}$ & c. $1730-35$ & $1.20 \pm 0.05$ & 999 & 0.12 & PHL \\
\hline Smith George of Chichester & Classical Landscape & c. $1760-70$ & $1.06 \pm 0.09$ & 86 & 0.07 & NGA \\
\hline Wilson Richard & Landscape with Bathers, Cattle and Ruin & c. $1770-75$ & $1.07 \pm 0.02$ & 88 & 0.07 & TTG \\
\hline Joseph Mallord William Turner & Sunset & c. $1820-30$ & $1.09 \pm 0.01$ & 100 & 0.08 & TTG \\
\hline Joseph Mallord William Turner & Running Wave in a Cross-Tide: Evening & c. $1820-30$ & $1.27 \pm 0.04$ & 100 & 0.14 & TTG \\
\hline Joseph Mallord William Turner & The Distant Tower: Evening & c. $1820-30$ & $1.09 \pm 0.02$ & 85 & 0.08 & TTG \\
\hline Joseph Mallord William Turner & Twilight over the Waters & c. $1820-30$ & $1.09 \pm 0.01$ & 100 & 0.08 & TTG \\
\hline Joseph Mallord William Turner & A Ruin: Sunset & c. $1820-30$ & $1.21 \pm 0.03$ & 100 & 0.13 & TTG \\
\hline Joseph Mallord William Turner & Sunset & c. $1820-30$ & $1.11 \pm 0.02$ & 100 & 0.09 & TTG \\
\hline Joseph Mallord William Turner & River: Sunset & c. $1820-30$ & $1.08 \pm 0.01$ & 70 & 999 & TTG \\
\hline Joseph Mallord William Turner & The Line of Cliffs & c. $1820-30$ & $1.17 \pm 0.01$ & 84 & 0.1 & TTG \\
\hline Joseph Mallord William Turner & River with Trees: Sunset & c. $1820-30$ & $1.10 \pm 0.00$ & 100 & 0.09 & TTG \\
\hline Joseph Mallord William Turner & River Scene: Sunset & c. $1820-30$ & $1.34 \pm 0.15$ & 100 & 0.16 & TTG \\
\hline Joseph Mallord William Turner & Studies of Skies & c. $1820-30$ & $1.14 \pm 0.01$ & 100 & 0.1 & TTG \\
\hline Joseph Mallord William Turner & Evening & c. $1820-30$ & $1.12 \pm 0.02$ & 73 & 999 & TTG \\
\hline
\end{tabular}


Table B1. Continued.

\begin{tabular}{|c|c|c|c|c|c|c|}
\hline Painter's Name & Title of Painting & Year & $\mathrm{R} / \mathrm{G}$ & SZA & AOD & Gallery* \\
\hline Joseph Mallord William Turner & The Castle by the Sea & c. $1820-30$ & $1.09 \pm 0.00$ & 100 & 0.09 & TTG \\
\hline Joseph Mallord William Turner & Sunset & c. $1820-30$ & $1.11 \pm 0.01$ & 100 & 0.09 & TTG \\
\hline Joseph Mallord William Turner & Study for 'The Golden Bough' & c. $1820-30$ & $1.12 \pm 0.02$ & 79 & 0.13 & TTG \\
\hline Joseph Mallord William Turner & Sunset over the Sea & c. $1820-30$ & $1.10 \pm 0.00$ & 86 & 0.08 & TTG \\
\hline Joseph Mallord William Turner & Rochester Castle and Bridge & c. $1820-30$ & $1.11 \pm 0.00$ & 90 & 0.09 & TTG \\
\hline Joseph Mallord William Turner & Sunset & c. $1820-30$ & $1.11 \pm 0.01$ & 100 & 0.09 & TTG \\
\hline Joseph Mallord William Turner & The Yellow Sky & c. $1820-30$ & $1.10 \pm 0.01$ & 100 & 0.09 & TTG \\
\hline Joseph Mallord William Turner & A Pink Sky above a Grey Sea & c. 1822 & $1.22 \pm 0.07$ & 100 & 0.13 & TTG \\
\hline Caspar David Friedrich & Moonrise by the Sea & c. 1822 & $1.32 \pm 0.02$ & 100 & 0.16 & NGB \\
\hline Joseph Mallord William Turner & A Stormy Sunset & c. 1822 & $1.13 \pm 0.01$ & 100 & 0.09 & TTG \\
\hline Joseph Mallord William Turner & Fiery Sunset & c. $1825-27$ & $1.30 \pm 0.03$ & 100 & 0.15 & TTG \\
\hline Joseph Mallord William Turner & Sunset over Water & c. $1825-27$ & $1.06 \pm 0.00$ & 82 & 0.08 & TTG \\
\hline Joseph Mallord William Turner & Sunset over a City & c. $1826-36$ & $1.19 \pm 0.01$ & 100 & 0.12 & TTG \\
\hline Joseph Mallord William Turner & Regulus & c. $1827-37$ & $1.01 \pm 0.01$ & 86 & 0.06 & TTG \\
\hline Caspar David Friedrich & Sunset (Brothers) & c. $1830-35$ & $1.66 \pm 0.05$ & 86 & 0.37 & HMT \\
\hline Caspar David Friedrich & $\begin{array}{l}\text { Mountainous River Landscape (Night } \\
\text { Version) }\end{array}$ & c. $1830-35$ & $1.78 \pm 0.04$ & 100 & 0.35 & SMK \\
\hline Sir Augustus Wall Callcott & Dutch Landscape with Cattle & c. $1830-40$ & $1.05 \pm 0.00$ & 63 & 999 & TTG \\
\hline Joseph Mallord William Turner & Sunset. (?Sunrise) & c. $1835-40$ & $1.33 \pm 0.05$ & 100 & 0.21 & TTG \\
\hline Joseph Mallord William Turner & A Lurid Sunset & c. $1840-45$ & $1.31 \pm 0.07$ & 100 & 0.15 & TTG \\
\hline Joseph Mallord William Turner & $\begin{array}{l}\text { Sunset Seen from a Beach with Breakwa- } \\
\text { ter }\end{array}$ & c. $1840-45$ & $1.32 \pm 0.03$ & 100 & 0.16 & TTG \\
\hline Joseph Mallord William Turner & The Rigi & c. 1841 & $1.12 \pm 0.02$ & 100 & 0.09 & TTG \\
\hline Joseph Mallord William Turner & Sunset From the Top of the Rigi & c. 1844 & $1.04 \pm 0.02$ & 999 & 0.07 & TTG \\
\hline Ralph Albert Blakelock & Landscape with Trees & c. $1880-90$ & $1.49 \pm 0.11$ & 100 & 0.27 & MAR \\
\hline Ralph Albert Blakelock & Edge of the Forest & c. $1880-90$ & $1.36 \pm 0.09$ & 100 & 0.22 & BKL \\
\hline Ralph Albert Blakelock & Afternoon Light & c. $1880-90$ & $1.32 \pm 0.06$ & 90 & 0.21 & MAR \\
\hline Gustav Klimt & Sappho & $1888-90$ & $1.65 \pm 0.05$ & 100 & 0.25 & $\mathrm{HCV}$ \\
\hline Joseph Mallord William Turner & Sea Monsters and Vessels at Sunset & c. 1845 & $1.39 \pm 0.03$ & 100 & 0.18 & TTG \\
\hline Joseph Mallord William Turner & Yellow and Blue Sunset over Water & c. 1845 & $1.07 \pm 0.00$ & 81 & 0.1 & TTG \\
\hline Joseph Mallord William Turner & Sunset at Ambleteuse & c. 1845 & $1.24 \pm 0.03$ & 100 & 0.13 & TTG \\
\hline Joseph Mallord William Turner & Sunset & c. 1845 & $1.21 \pm 0.02$ & 100 & 0.13 & TTG \\
\hline Joseph Mallord William Turner & Yellow Sunset & c. 1845 & $1.32 \pm 0.07$ & 85 & 0.16 & TTG \\
\hline Joseph Mallord William Turner & The Red Rigi: Sample Study & c. $1841-42$ & $1.12 \pm 0.02$ & 69 & 999 & TTG \\
\hline Albert Bierstadt & South and North Moat Mountains & c. 1862 & $0.99 \pm 0.01$ & 60 & 999 & PRV \\
\hline Albert Bierstadt & White Horse and Sunset & c. 1863 & $1.22 \pm 0.03$ & 100 & 0.13 & $\mathrm{BBH}$ \\
\hline Albert Bierstadt & Evening on the Prarie & c. 1870 & $1.07 \pm 0.01$ & 91 & 0.08 & TBM \\
\hline Albert Bierstadt & Sacramento River Valey & c. 1872 & $1.06 \pm 0.01$ & 88 & 0.08 & TBM \\
\hline
\end{tabular}


Table B2. Galleries abbreviations:

AIC: The Art Institute of Chicago, USA

ALP: Alte Pinakothek, Munich, Germany AMA: Allen Memorial Art Museum, Oberlin, Ohio, USA

BAB: Museo de Bellas Artes, Bilbao, Spain

BBH:Buffulo Bill Historical Center, USA

BKL: Brooklyn Museum, NY, USA

BRN: British National Museum, London

BVB: Museum Boijmans Van Beuningen, Rotterdam, The Netherlands

CHR: Chrysler Collection, Norfolk, Virginia, USA

CHW: Castle Howard, Yorkshire, UK

CTI: Courtauld Institute Galleries, London, UK

EVR: Everson Museum of Art, USA

FAB: Museum of Fine Arts, Boston, USA

FAB: Museum of Fine Arts, Budapest, Hungary

FAF: Fine Arts Museums of San Francisco, California, USA

FGA: Fogg Art Museum, Harvard University, Cambridge, Massachusetts

FLK: Museum Folkwang, Essen, Germany

FRW: Farnsworth Art Museum, Rockland, ME.

GDA: Gallerie dell'Accademia, Venice, Italy

GML: Gemaldegalerie Neue Meister, Staatliche Kunstsammlungen, Dresden

GPL: Griefswald, Pommersches Landmuseum, Germany

GTT: The J. Paul Getty Museum, Malibu, CA, USA

HAU: Herzog Anton Ulrich-Museum, Brunswick

HCV: Historical Museum of the City of Vienna, Vienna, Aus-

tria

HGG: Haggin Museum, USA

HMA: Hiroshima Museum of Art, Japan

HMT: The Hermitage Museum, St. Petersburg, Russia

HTB: Huis ten Bosch, The Hague

KDE: Kunstmuseum Dusseldorf im Ehrenhof, Dusseldorf, Germany

KNH: Kunsthalle, Hamburg, Germany

KNH: Kunsthistorisches Museum, Vienna, Austria

KNM: Kunstmuseum, Winterthur

LCS: Leicestershire Museum and Art Gallery

LVR : Musee du Louvre, Paris, France

MAR: Memorial Art Gallery of the University of Rochester, USA

MBK: Museum der Bildenden Kunste, Leipzig, Germany

MKK: Museum fur Kunst und Kulturgeschichte, Dortmund
MMA: The Metropolitan Museum of Art, New York City,

USA

MNG: Manoogian Collection

NAA: National Museum of American Art, USA

NCF: Newington Cropsey Foundation Gallery of Art

NGA: National Gallery of Art, Washington, USA

NGB: Nationalgalerie, Berlin, Germany

NGL: The National Gallery, London, UK

NGO: The National Gallery, Oslo, Norway

NPM: Neue Pinakothek, Munich, Germany

NSM: Norton Simon Foundation, Pasadena

OKL: The Oakland Museum of California, USA

ORF: Oskar Reinhart Foundation, Winterthur

ORS: Musee d'Orsay, Paris, France

PHL: Philadelphia Museum of Art, USA

PLP: Palazzo Pitti, Galleria Palatina, Florence, Italy

PRD: Museo del Prado, Madrid, Spain

PRV: Private collection

RBA: Musee Royal des Beaux Arts, Antwerp, Belgium

RBA: Musees Royaux des Beaux-Arts, Brussels, Belgium

RCA:Russell-Cotes Art Gallery and Museum, Bournemouth,

England

RCL:Royal Collection, London, UK

RPC: Musee Rupert de Chievres, Poitiers

RSS: The Russian Museum, St-Petersburg, Russia

SCH: Schloss Scharlattenburg, Stiftung Preussische Berlin,

Germany

SCN: Sciencemuseum, London, UK

SFS: Museum Schloss Fasanerie, Eichenzell

SMK: Staatliche Museen Kassel

SPF: Susan Powell Fine Art, NY, USA

STL: Staatliche Museen, Berlin, Germany

TAS: Thomas Agnew \& Sons Ltd., UK

TBM: Thyssen-Bornemisza Museum, Spain

TLD: Toledo Museum of Art, USA

TRV: The Tretyakov Gallery, Moscow, Russia

TTG: The TTG

WLC: Wallace Collection, London, UK

WLR: Wallraf-Richartz Museum, Cologne, Germany
Acknowledgements. This work has been partially supported by EU GOCE-CT-2004-003893 and while one of us was a post doc scholar from IKY at the National Technical University of Athens. The authors are indebted to B. Mayer, H. Graf, D. Stevenson and two anonymous reviewers for their valuable comments and suggestions.

Edited by: F. J. Dentener

\section{References}

Anderson, G., Clough, S., Kneizys, F., Chetwynd, J., and Shettle, E.: AFGL Atmospheric Constituent Profiles (0-120 km), Air Force Geophysics Laboratory, AFGL-TR-86-0110, Environmental Research Paper No. 954, 1986.

Bockemuhl, M., "Turner", Taschen, 2000.

Clausen, H. B. and Hammer, C. U.: The Laki and Tambora eruptions as revealed in Greenland ice cores from 11 locations, An- 
nals of Glaciology 10, 16-22, 1988.

Deirmendijian, D.: On Volcanic and Other Particulate Turbidity Anomalies, Advan. Geophys., 16, 267-296, 1973.

Hammer, C. U., Clausen, H. B., and Dansgaard, W.: Greenland ice sheet evidence of post-glacial volcanism and its climatic impact, Nature, 288, 230-235, 1980.

Humphreys, W. J.: Physics of the air, New York and London: McGraw-Hill, 1940.

Jameson, D. and Hurvich, L. M.: Some quantitative aspects of an opponent-colors theory I, Chromatic responses and spectral saturation, J. Opt. Soc. Am., 45, 546-552, 1955.

Kylling, A., Bais, A. F., Blumthaler, M., Schreder, J., Zerefos, C. S., and Kosmidis E.: Effect of aerosols on solar UV irradiances during the Photochemical Activity and Solar Ultraviolet Radiation campaign, J. Geophys. Res., 103(20), 26 051-26 060, 1998.

Lamb, H. H.: Volcanic dust in the atmosphere, with a chronology and assessment of its meteorological significance, Philos. Trans. R. Soc. London, Ser. A, 266, 425-533, 1970.

Lamb, H. H.: Supplementary volcanic dust veil assessments, Climate Monitor, 6, 57-67, 1977

Lamb, H. H.: Uptake of the chronology of assessments of the volcanic dust veil index, Climate Monitor, 12, 79-90, 1983.

Mayer, B. and Kylling, A.: Technical note: The LibRadtran software package for radiative transfer calculations: Description and examples of use, Atmos. Chem. Phys., 5, 1855-1877, 2005

Mayer, B. and Emde, C.: Comment on "Glory phenomenon informs of presence and phase state of liquid water in cold clouds" by Nevzorov, A. N., Atmos. Res., 84, 410-419, 2007

Newhall, C. G. and Self, S.: The volcanic explosivity index (VEI): an estimate of explosive magnitude for historical volcanism, J. Geophys. Res., 87, 1231-1238, 1982.

Nicolet, M.: On the molecular scattering in the terrestrial atmosphere: An empirical formula for its calculation in the homosphere, Planet. Space Sci., 32, 1467-1468, 1984.

Robertson, A., Overpeck, J, Rind, D., Mosley-Thompson, E., Zielinski, G., Lean, J., Koch, D., Penner, J., Tegen I., and Healy, R.: Hypothesized climate forcing time series for the last 500 years, J. Geophys. Res., 106(D14), 14 783-14 803, 2001.

Robock, A. and Free M. P.: The volcanic record in ice cores for the past 2000 years, in Climatic Variations and Forcing Mechanisms for the Past 2000 Years, edited by: Jones, P. D. and Bradley, R. S., Springer-Verlag, New York, 533-546, 1996.

Robock, A. and Free, M. P.: Ice cores as an index of global vol- canism from 1850 to the present, J. Geophys. Res., 100, $11549-$ $11567,1995$.

Robock, A.: A latitudinally dependent volcanic dust veil index, and its effect on climate simulations, J. Volcanol. Geotherm. Res., 11, 67-80, 1981.

Robock, A.: Volcanic eruptions and climate, Rev. Geophys., 38, 191-219, 2000.

Sandick, R. A.: In het rijk van Vulcaan. De uitbarsting van Krakatau en hare gevolgen, Zutphen, W.J. Thieme \& Cie, 1890.

Sapper, K.: Beitrage zur Geographie der tatigen Vulkane, Z. Vulk, Berlin 3, 65-197, 1917.

Sato, M., Hansen, J. E., McCormick, M. P., and Pollack, J. B.: Stratospheric aerosol optical depths 1850-1990, J. Geophys. Res., 98, 22 987-22 994, 1993.

Schefrin, B. E. and Werner, J. S.: Loci of spectral unique hues throughout the life span, J. Opt. Soc. Am. A, 7, 305-311, 1990.

Shaw, N.: Manual of meteorology, vol. II: Comperative meteorology, Cambridge University Press, 1936.

Shevell, S. (Ed.): The science of color, 2nd edition, Optical Society of America, Elsevier, 2003.

Stamnes, K., Tsay, S.-C., Wiscombe, W., and Jayaweera, K.: Numerically stable algorithm for discrete-ordinate-method radiative transfer in multiple scattering and emitting layered media, Appl. Optics, 27, 2502-2509, 1988.

Stothers, R. B.: Major optical depth perturbations to the stratosphere from volcanic eruptions: Pyrheliometric period 18811960, J. Geophys. Res., 101, 3901-3920, 1996.

Stothers, R. B.: Mystery cloud of AD 536. Nature 307, 344-345, 1984a.

Stothers, R. B.: The great Tambora eruption in 1815 and its aftermath, Science, 224, 1191-1198, 1984 b.

Symons, G. J. (Ed.): The eruption of Krakatoa and subsequent phenomena, 494pp. London, Trubner and Co., 1888.

Wyszecki, G. and Stiles, W. S.: Color Science - Concepts and Methods, Quantitative Data and Formulae, 2nd edn. New York: John Wiley and Sons, 1982.

Zielinski, G. A.: Use of paleo-records in determining variability within the volcanism-climate system, Quat. Sci. Rev., 19, 417438, 2000.

Zielinski, G. A.: Stratospheric loading and optical depth estimates of explosive volcanism over the last 2100 years derived from the GISP2 Greenland ice core, J. Geophys. Res., 100, $20937-$ $20955,1995$. 